\title{
WHAT CAN EARTH HISTORY AND EVOLUTION TELL ABOUT THE CREATOR OF THE UNIVERSE?
}

\author{
Dr. Andreas MAY, \\ Dr. Andreas May was professor at the Saint Louis University - Madrid campus and authored \\ numerous publications on geological and palaeontological topics. Now he works as a \\ computer scientist in a large German company, \\ GERMANY, \\ Email: may_devonian@yahoo.es
}

\begin{abstract}
Conclusions about the Creator of the universe are drawn from the evolution and diversity of living beings. Furthermore, four events of the Earth's history are addressed. From them, it can be concluded that the Creator actively intervened in the history of the Earth to promote the development of intelligent life. Following characteristics of the Creator are observed: He is patient, creates an exuberant fullness, and gives freedom to his creation. He uses causal links and seemingly random events to steer the course of his creation. The Creator is in constant dialogue with his creation to lead it into ever greater abundance and freedom. He uses evolutionary processes, which are not goal-oriented, to achieve his goals. The observed characteristics of the Creator fit very well with the Judeo-Christian God. The question is raised whether the Creator is timeless or not.
\end{abstract}

Keywords: Earth history; intelligent life, palaeontology; Christianity; freedom; dialogue; natural theology; theistic evolution;

\section{INTRODUCTION}

Many people of our planet are convinced that this universe has a Creator, a transcendent superior intelligence. There are different ways to learn more about this Creator: religious revelations, philosophical reflections, and observation of the nature that surrounds us. The ways of religious revelation and philosophical reflection have been taken for a long time; however, they have the disadvantage that their intersubjective verifiability is more or less limited. Since the rise of the natural sciences, therefore, a third way - the study of nature - has become increasingly important and there is a great deal of literature on it. This study of nature is based on the assumption that "some aspects of the natural world reflect something about its creator." 1

In the attempt to obtain clues through the observation of nature, as to whether there is a transcendent Creator of the universe and what properties he might have, astronomical and physical topics - such as quantum physics, fundamental physical constants and the origin of the universe - are often considered in the literature. I would like to mention in particular:

- It seems that there is a "fine-tuning" of the fundamental physical constants that are necessary for the development of life. Various authors derive the anthropic principle

\footnotetext{
${ }^{1}$ Rope Kojonen, R. "Natural theology in evolution: a review of critiques and changes", in European Journal for Philosophy of Religion 9 (2017), p. 87.
} 
from this observation - Barrow and Tipler deserve special mention. ${ }^{2}$ A critical overview of the literature on the anthropic principle is provided by Mosterín. ${ }^{3}$ For many authors, this "fine-tuning" proves the existence of an intelligent Creator. ${ }^{4}$

- Another research area derives from Heisenberg's uncertainty principle. It is not possible to predict exactly the position and motion of a particle at the same time, but one can only indicate probabilities. ${ }^{5}$ Quantum physics brings indeterminacy into the universe. ${ }^{6}$ Therefore, the future is no longer clearly calculable. Peters even goes so far as to say that the indeterminacy of quantum physics is a necessary prerequisite for human freedom. ${ }^{7}$ Furthermore, several authors argue that the Creator of the universe could use the indeterminacy of quantum physics to intervene in this immanent universe without coming into conflict with any laws of nature. ${ }^{8}$

These are topics where the time component does not play such a big role.

However, in this article, I analyse topics for which the course of time is of essential importance, namely the history of the Earth as well as the evolution of living beings and the

${ }^{2}$ John D. Barrow / Frank J. Tipler, The Anthropic Cosmological Principle, Oxford University Press, Oxford, 1988.

3 Jesús Mosterín, “Anthropic explanations in cosmology”, in Petr Hájek, Luis Valdés-Villanueva, and Dag Westerståhl (eds.), Logic, Methodology and Philosophy of Science: Proceedings of the Twelfth International Congress, College Publications, London, 2004, pp. 441-472.

${ }^{4}$ Alister E. McGrath, A Fine-Tuned Universe: The Quest for God in Science and Theology, Westminster John Knox Press, London, 2009; Tim J. Mawson, "Explaining the fine tuning of the universe to us and the fine tuning of us to the universe", in Royal Institute of Philosophy Supplements 6 (2011), pp. 25-50; Glenn Siniscalchi, "Fine-tuning, atheist criticism, and the fifth way", in Theology and Science 12 (2014), pp. 64-77; Roger Tucker, "Fine tuning mission to reach those influenced by Darwinism", in Verbum et Ecclesia 35 (2014), a891, https://doi.org/10.4102/ve.v35i1.891, 06.05.2021; David H. Glass and Mark McCartney, "Explaining and explaining away in science and religion", in Theology and Science 12 (2014), pp. 338-361; Walter L. Bradley, "The fine tuning of the universe: evidence for the existence of God?", in Perspectives on Science and Christian Faith 70 (2018), pp. 147-160; Jason Waller, Cosmological Fine-Tuning Arguments: What (if Anything) Should We Infer from the Fine-Tuning of Our Universe for Life?, Routledge, London, 2019; Richard Swinburne, The Existence of God. Second Edition, Oxford University Press, Oxford, 2004, pp. 172-188.

${ }^{5}$ Charles H. Townes, "Basic puzzles in science and religion", in Ted Peters and Nathan Hallanger (eds.), God's Action in Nature's World, Essays in Honour of Robert John Russell, Ashgate, Aldershot, UK, 2006, p. 130.

${ }^{6}$ George F. R. Ellis, "Necessity, purpose, and chance", in Robert John Russell and Joshua M. Moritz (eds.), God's Providence and Randomness in Nature: Scientific and Theological Perspectives, Templeton Press, West Conshohocken, PA, 2019, pp. 21-68; Dillard W. Faries, "A personal God, chance, and randomness in quantum physics", in Perspectives on Science and Christian Faith 66 (2014), pp. 13-22; Chris Barrigar, "God's agape/probability design for the universe", in Perspectives on Science and Christian Faith 70 (2018), pp. 163164.

${ }^{7}$ Ted Peters, "Contingency and freedom in brains and selves", in Robert John Russell and Joshua M. Moritz (eds.), God's Providence and Randomness in Nature: Scientific and Theological Perspectives, Templeton Press, West Conshohocken, PA, 2019, pp. 278-280.

${ }^{8}$ Charles H. Townes, "Basic puzzles"; Marcos Ruiz Soler and Ignacio Núñez de Castro, "La kénosis del Dios trinitario: reflexiones desde la teología de la naturaleza", in Estudios Eclesiásticos, Revista de investigación e información teológica y canónica 92, no. 360, (2017), pp. 61-62; George L. Murphy, "The nuts and bolts of creation", in Perspectives on Science and Christian Faith 70 (2018), p. 57; Daekyung Jung, "The RNA world and divine action in and through quantum mechanics", in Theology and Science 16 (2018), pp. 498-519; Ted Peters, "Science and Religion: Ten Models of War, Truce, and Partnership", in Theology and Science 16 (2018), pp. 31-34; Robert John Russell, Cosmology from Alpha to Omega: The Creative Mutual Interaction of Theology and Science, Fortress Press, Minneapolis, 2008; Robert John Russell, "What we've learned from quantum mechanics about noninterventionist objective divine action in nature - and its remaining challenges", in Robert John Russell and Joshua M. Moritz (eds.), God's Providence and Randomness in Nature: Scientific and Theological Perspectives, Templeton Press, West Conshohocken, PA, 2019, pp. 133-172. 
resulting diversity of forms. This broadening of the view opens up new perspectives on topics that have been discussed in literature since long time.

First, I will briefly outline the diversity of living beings on Earth today and their evolution. Second, I will describe four events in the history of the Earth which were necessary for the present diversity of living beings and the present human civilisation to develop. I will explain why they can be interpreted as interventions of the Creator of the universe. Then I will use these data to derive important characteristics of the Creator. A Creator will become visible, who leads his creation in a constant dialogue to ever greater freedom and abundance. These character traits fit very well with the God of Judaism and Christianity. Finally, I will discuss three specific aspects of the assumption of a dialogue between the Creator and the creation.

\section{EVIDENCE FROM BIOLOGY AND PALAEONTOLOGY}

\subsection{The diversity of life}

Today the planet Earth is inhabited by an abundance of different living beings, an exuberant diversity of forms that biology has not yet been able to grasp fully. Many people do not adequately perceive this diversity of forms because they lack the necessary biological knowledge. What at first glance looks like one kind of living being often comprises many very different species. As an example I would like to take my home country Germany: Let us look at the frequent living beings grass, beetle and mouse. In Germany there are several hundred grass species, 7,000 beetle species and dozens of species of mouse-like small mammals. And yet Germany is anything but a hot spot of biodiversity.

Another example is that more than 22,000 orchid species are known worldwide. ${ }^{9}$ But orchids are only one family of the flowering plants (phylum Anthophyta) and flowering plants are only one phylum of the kingdom Plantae. In addition to the kingdom Plantae exist the kingdom Animalia, the kingdom Fungi, the kingdom Protista (unicellular organisms with nucleus), and the kingdom Monera (unicellular organisms without nucleus). ${ }^{10}$ According to Chapman, if all the kingdoms of living beings are taken together, 1.9 million (!) species are known and it is supposed that a total of 11 million different species exist in the world today. ${ }^{11}$ Mora et al. come to similar numbers. ${ }^{12}$

Breaking down these numbers, there are at least 4,300 species of mammals and at least 9,000 species of birds on our planet today, but that is little compared to the million species of insects. ${ }^{13}$ The kingdom Animalia has a total of 1.4 million species, while the kingdom Plantae has 310,000 species. Of these, 268,000 species are flowering plants. ${ }^{14}$ Furthermore, it should be noted that Rödder, Ziegler, and Falk estimate that in total as many as 180 million animal species have existed over the entire history of the Earth. ${ }^{15}$

\footnotetext{
9 Jing Cai et al., "The genome sequence of the orchid Phalaenopsis equestris", in Nature genetics 47 (2015), p. 65.

${ }^{10}$ Neil A. Campbell / Jane B. Reece, Biology, 6th ed., Pearson Education, San Francisco, 2002, pp. 522-523.

11 Arthur D. Chapman, Numbers of Living Species in Australia and the World, 2nd ed., Canberra, Australia, 2009, p. 11.

12 Camilo Mora et al., "How many species are there on earth and in the ocean?", in PLoS Biology 9, no. e1001127 (2011), pp. 1-8, https://doi.org/10.1371/journal.pbio.1001127, 06.05.2021.

${ }^{13}$ Arthur D. Chapman, Numbers of Living.

${ }^{14}$ Arthur D. Chapman, Numbers of Living.

${ }^{15}$ Gerhard Rödder, Fred-Karsten Ziegler, and Eberhard Falk, "Wie viele Arten? Der Stand der Forschung gegen Ende des Jahrhunderts”, in Paläontologische Zeitschrift 67 (1993), p. 220.
} 


\subsection{Evolution}

For over 200 years, biology and palaeontology have been providing an overwhelming wealth of evidence that the diversity of living beings observable today has evolved in geological periods from other, more primitive organisms and that probably all living beings on this planet had the same living cell as their first ancestor.

The first reliable evidence of life are structures in 3.7 billion years old sediments that were produced by bacteria or similar microbes. ${ }^{16}$ Fossils of dividing bacteria have been found in sediments 3.4 billion years old. ${ }^{17}$ At first, the evolution of life was very slow, but since the beginning of the Cambrian, 541 million years ago, it has accelerated. By studying the fossils, palaeontology can confirm that the diversity of living organisms observable today and in Earth history has evolved from a small number of body plans. ${ }^{18}$

Whereas palaeontologists can only say something about the evolution of those living beings of which fossils are known, biology can also make far-reaching statements by examining the DNA. It is a well-founded hypothesis that all living beings today are descendants of a single very primitive living cell. If one compares the sequence of the nucleic bases in a certain DNA strand between different organisms, one can recognise when the common ancestors of these organisms separated from each other. The result is a family tree with a kind of "molecular clock", ${ }^{19}$ whose abstract times can be converted into years by comparing corresponding fossil finds. As a result of these investigations, Betts et al. come to the conclusion that the last common ancestor of all living beings on Earth existed more than 3.9 billion years ago. ${ }^{20}$ This would mean that life on Earth must have arisen shortly after the Earth's crust had cooled to such an extent that the condensing water could fill the first oceans. The diversity of life on Earth, including us humans, has developed from this first primitive cell.

\section{IMPORTANT EVENTS IN EARTH'S HISTORY}

In order for the first primitive living cell to develop into today's abundance and diversity of life and human civilisation, various extraordinary circumstances and events were necessary throughout the history of the Earth. In the following I would like to highlight four events in particular and explain why they were necessary.

I limit myself here to events that have something extraordinary about them. That is why I will not mention here that, about 2.8 million years ago Australopithecus afarensis split into two lines: on the one hand, the line that leads to us; on the other hand, the line of Paranthropus. ${ }^{21}$ Although this event was of central importance for the emergence of the

\footnotetext{
${ }^{16}$ Allen P. Nutman et al., "Rapid emergence of life shown by discovery of 3,700-million-year-old microbial structures", in Nature 537 (2016), pp. 535-538.

${ }^{17}$ Frances Westall et al., "Early Archean fossil bacteria and biofilms in hydrothermally-influenced sediments from the Barberton greenstone belt, South Africa", in Precambrian Research 106 (2001), pp. 93-116; Scott Freeman / Jon C. Herron, Evolutionary analysis, 3rd ed., Pearson Education, Upper Saddle River, NJ, 2003, p. 638.

${ }^{18}$ Neil A. Campbell / Jane B. Reece, Biology, pp. 635-643.

${ }^{19}$ Scott Freeman / Jon C. Herron, Evolutionary analysis, p. 571.

${ }^{20}$ Holly C. Betts et al., "Integrated genomic and fossil evidence illuminates life's early evolution and eukaryote origin”, in Nature Ecology \& Evolution 2 (2018), pp. 1556-1562.

${ }^{21}$ Friedemann Schrenk and Timothy G. Bromage, "Origins of hominin biocultural diversity", in Nicole Rupp et al. (eds.), Winds of Change: Archaeological Contributions in Honour of Peter Breunig, Verlag Dr. Rudolf Habelt, Bonn, 2017, pp. 409-419 (pp. 412-414); Zeresenay Alemseged et al., "Fossils from Mille-Logya, Afar, Ethiopia, elucidate the link between Pliocene environmental changes and Homo origins", in Nature Communications 11, no. 2480 (2020), pp. 1-12, https://doi.org/10.1038/s41467-020-16060-8, 04.05.2021;
} 
genus Homo, it can be explained simply by the fact that two different populations of Australopithecus afarensis reacted in different ways to the climate-induced increase in the grass-rich savannah. In the ancestors of Paranthropus, natural selection led to a strengthening of the dentition and chewing muscles to be able to chew harder plant food. In contrast, our ancestors learned to use tools to work the food and they increased meat consumption. ${ }^{22}$

\subsection{Collision with a Mars-sized body}

About 4.53 billion years ago, a body about the size of Mars collided with Earth. ${ }^{23}$ This unimaginably violent collision released an enormous amount of energy and caused the following:

- Our moon was formed. ${ }^{24}$

- The planet Earth was melted down to the core and the heavy metals sank down. In this way developed the present zonation of Earth's interior with a solid metallic inner core and a liquid metallic outer core. ${ }^{25}$

- The Earth's axis of rotation is no longer perpendicular to the Earth's orbit around the Sun, but inclined against it (axial tilt). ${ }^{26}$

Even without the gigantic collision with a Mars-sized body there probably would be life on Earth. Nevertheless, the above mentioned consequences of this collision have been very beneficial for the evolution of a diverse life on Earth:

- The interaction between the solid metallic inner core and the liquid metallic outer core creates the strong magnetic field of the Earth. This magnetic field protects us

Andrew Du et al., "Statistical estimates of hominin origination and extinction dates: A case study examining the Australopithecus anamensis-afarensis lineage", in Journal of Human Evolution 138, no. 102688 (2020), pp. 113, https://doi.org/10.1016/j.jhevol.2019.102688, 30.04.2021.

${ }^{22}$ Vincent Balter et al., "Evidence for dietary change but not landscape use in South African early hominins", in Nature 489 (2012), pp. 558-560.

23 David J. Stevenson, "Origin of the moon - The collision hypothesis", in Annual Review of Earth and Planetary Sciences 15 (1987), pp. 271-315; Alex N. Halliday, "Terrestrial accretion rates and the origin of the Moon", in Earth and Planetary Science Letters 176 (2000), pp. 17-30; Daniel Herwartz et al., "Identification of the giant impactor Theia in lunar rocks", in Science 344 (2014), pp. 1146-1150; Charles F. Gammie, Wei-Ting Liao, and Paul M. Ricker, "A hot big bang theory: magnetic fields and the early evolution of the protolunar disk", in The Astrophysical Journal 828 (2016), pp. 1-9, https://iopscience.iop.org/article/10.3847/0004637X/828/1/58/meta, 28.04.2021; Edward D. Young et al., "Oxygen isotopic evidence for vigorous mixing during the Moon-forming giant impact”, in Science 351 (2016), pp. 493-496; Frank Press / Raymond Siever, Understanding Earth, 3rd ed.,W. H. Freeman and Company, New York, 2000, pp. 8-9; Martin Redfern, 50 Schlüsselideen Erde, Quercus Books, London 2014, p. 8; John W. Valley et al., "Hadean age for a post-magmaocean zircon confirmed by atom-probe tomography", in Nature Geoscience 7 (2014), pp. 219-223.

${ }^{24}$ David J. Stevenson, "Origin of the moon"; Alex N. Halliday, "Terrestrial accretion rates"; Robin M. Canup and Erik Asphaug, "Origin of the Moon in a giant impact near the end of the Earth's formation", in Nature 412 (2001), pp. 708-712; Daniel Herwartz et al., "Identification of the giant"; Charles F. Gammie, Wei-Ting Liao, and Paul M. Ricker, "A hot big bang"; Edward D. Young et al., "Oxygen isotopic evidence"; Joseph L. Spradley, "Ten lunar legacies: Importance of the Moon for life on Earth", in Perspectives on Science and Christian Faith 62 (2010), pp. 267-275.

${ }^{25}$ Frank Press / Raymond Siever, Understanding Earth, pp. 9-10; Martin Redfern, 50 Schlüsselideen Erde, pp. 9; Douglas Rumble et al., "The oxygen isotope composition of earth's oldest rocks and evidence of a terrestrial magma ocean", in Geochemistry, Geophysics, Geosystems 14 (2013), pp. 1929-1939; John W. Valley et al., "Hadean age".

${ }^{26}$ Joseph L. Spradley, "Ten lunar legacies”, pp. 269-270. 
from high-energy charged particles from space (such as the solar wind), because it captures these particles in the so-called "Van Allen belts". 27

- The axial tilt of the Earth's axis causes seasons on Earth.

- Due to the existence of the moon, we have the tides on Earth - ebb and flow.

Only because of this collision do we have tides, seasons and the Van Allen belts, which protect us from high-energy charged particles from space. Without the Van Allen belts as well, primitive life could have originated in the oceans. Nevertheless, the high-energy charged particles from space would have prevented or at least made very difficult the leaving of the water. Seasons and tides cause changes in environmental conditions that can stimulate the further evolution and diversification of living beings. In consequence, without this gigantic collision life on Earth would not have evolved as far and as diverse as it is today, on an Earth without seasons, without tides and especially without the protective Van Allen belts.

\subsection{Oxygen content of the atmosphere}

Over the last 4 billion years, always most of the water on Earth has been in a liquid state. This is absolutely necessary for the emergence and evolution of life. Nevertheless, the Sun's brightness has increased by about 25 percent over the past 4.5 billion years. ${ }^{28}$ Had we had an atmosphere of today's composition 4 or 3 billion years ago, all water on Earth would have frozen to ice. Fortunately, at that time we had an atmosphere without free oxygen, which produced a much stronger greenhouse effect. ${ }^{29}$ Therefore, despite the weaker sun, the Earth had a life-friendly temperature.

The invention of water-splitting photosynthesis by cyanobacteria released oxygen. 2.4 billion years ago, the atmosphere contained a significant amount of oxygen. ${ }^{30}$ The more oxygen there was in the atmosphere, the less was the greenhouse effect. If water-splitting photosynthesis had been invented much earlier, or if too much oxygen had been produced too early, our planet and life on it would literally have frozen. But if the production of oxygen had started much later, or had been too low, life on Earth probably would have died trough overheating...

\subsection{Mass extinction at the end of the Cretaceous period}

The extinction at the end of the Cretaceous period, 66 million years ago, wiped out 76 percent of all species, ${ }^{31}$ including all dinosaurs. Today, there is no doubt that this mass extinction was caused by the impact of a giant asteroid, which was probably 6-10 kilometres

\footnotetext{
${ }^{27}$ Martin Redfern, 50 Schlüsselideen Erde, p. 37; Joseph L. Spradley, “Ten lunar legacies”, p. 270.

${ }^{28}$ Tjeerd H. van Andel, New Views on an Old Planet: A History of Global Change, 2nd ed., Cambridge University Press, Cambridge, 1994, p. 287; David C. Catling and Kevin J. Zahnle, "The Archean atmosphere", in Science Advances 6, no. eaax1420 (2020), p. 8, https://advances.sciencemag.org/content/6/9/eaax1420, 20.04.2021.

${ }_{29}^{29}$ Tjeerd H. van Andel, New Views, pp. 280-289; David C. Catling and Kevin J. Zahnle, "The Archean atmosphere".

${ }^{30}$ Andrew H. Knoll and Martin A. Nowak, "The timetable of evolution", in Science Advances 3, no. e1603076 (2017), p. 2, https://advances.sciencemag.org/content/3/5/e1603076, 24.04.2021; Lewis J. Alcott, Benjamin J. W. Mills, and Simon W. Poulton, "Stepwise Earth oxygenation is an inherent property of global biogeochemical cycling”, in Science 366 (2019), pp. 1333-1337; David C. Catling and Kevin J. Zahnle, "The Archean atmosphere".

${ }^{31}$ David Jablonski, “Extinctions: A paleontological perspective”, in Science 253 (1991), p. 755.
} 
in diameter. When this asteroid hit the Earth, it produced the Chicxulub crater in the north of the Yucatan peninsula in Mexico. ${ }^{32}$

While the dinosaurs lived, the mammals were small and only of minor importance. Maor et al. believe that nocturnality may have allowed mammals to avoid antagonistic interactions with diurnal dinosaurs. ${ }^{33}$ The dominance of dinosaurs prevented the further diversification and evolution of mammals. Only after the extinction of the dinosaurs were the mammals able to develop their present diversity and importance. ${ }^{34}$ If this asteroid had passed the Earth, dinosaurs would probably still dominate the world now and the most highly developed primates would not be humans, but the prosimians!

\subsection{Interbreeding with Neanderthals}

All races and tribes of the modern-day Homo sapiens who live outside Africa or north of the Sahara are descendants of a single group from Northeast Africa who emigrated from Africa about 70,000 years ago. ${ }^{35}$ Shortly after this group of Homo sapiens emigrated from Africa, about 55,000-60,000 years ago, they interbred with the Neanderthal Homo neanderthalensis in the Near or Middle East. ${ }^{36}$ Hence, all non-Africans today have about $2 \%$

\footnotetext{
${ }^{32}$ David A. Kring, "The Chicxulub impact event and its environmental consequences at the Cretaceous-Tertiary boundary", in Palaeogeography, Palaeoclimatology, Palaeoecology 255 (2007), pp. 4-21; Frank Press / Raymond Siever, Understanding Earth, pp. 559-561; Scott Freeman / Jon C. Herron, Evolutionary analysis, pp. 686-691; Martin Redfern, 50 Schlüsselideen Erde, pp. 168-171; Alfio Alessandro Chiarenza et al., "Asteroid impact, not volcanism, caused the end-Cretaceous dinosaur extinction", in Proceedings of the National Academy of Sciences of the United States of America 117 (2020), pp. 17084-17093.

${ }^{33}$ Roi Maor et al., "Temporal niche expansion in mammals from a nocturnal ancestor after dinosaur extinction", in Nature Ecology \& Evolution 1 (2017), pp. 1889-1895.

${ }^{34}$ Robert W. Meredith et al., "Impacts of the Cretaceous terrestrial revolution and KPg extinction on mammal diversification", in Science 334 (2011), pp. 521-524; Maureen A. O'Leary et al., "The placental mammal ancestor and the post-K-Pg radiation of placentals", in Science 339 (2013), pp. 662-667; Thomas John Dixon Halliday, Paul Upchurch, and Anjali Goswami, "Eutherians experienced elevated evolutionary rates in the immediate aftermath of the Cretaceous-Palaeogene mass extinction", in Proceedings of the Royal Society B 283, no. 20153026 (2016), pp. 1-8, https://doi.org/10.1098/rspb.2015.3026, 11.05.2021; Christopher A. Emerling, Frédéric Delsuc, and Michael W. Nachman, "Chitinase Genes (CHIAs) provide genomic footprints of a post-Cretaceous dietary radiation in placental mammals", in Science Advances 4, no. eaar6478 (2018), pp. 110, https://advances.sciencemag.org/content/4/5/eaar6478, 20.04.2021.

${ }^{35}$ Scott Freeman / Jon C. Herron, Evolutionary analysis, pp. 752-759; Pedro Soares et al., "The expansion of mtDNA haplogroup L3 within and out of Africa", in Molecular Biology and Evolution 29 (2012), pp. 915-927; Qiaomei Fu et al., "A revised timescale for human evolution based on ancient mitochondrial genomes", in Current Biology 23 (2013), pp. 553-559; Luca Pagani et al., "Tracing the route of modern humans out of Africa by using 225 human genome sequences from Ethiopians and Egyptians", in The American Journal of Human Genetics 96 (2015), pp. 986-991; Anna-Sapfo Malaspinas et al., "A genomic history of Aboriginal Australia", in Nature 538 (2016), pp. 207-214; Ludovica Molinaro and Luca Pagani, "Human evolutionary history of Eastern Africa", in Current Opinion in Genetics \& Development 53 (2018), pp. 134-135.

${ }^{36}$ Richard E. Green et al., "A draft sequence of the Neandertal genome", in Science 328 (2010), pp. 710-722; Qiaomei Fu et al., "Genome sequence of a 45,000-year-old modern human from western Siberia", in Nature 514 (2014), pp. 445-449; Anna-Sapfo Malaspinas et al., "A genomic history”; Michael Dannemann and Fernando Racimo, "Something old, something borrowed: admixture and adaptation in human evolution", in Current Opinion in Genetics \& Development 53 (2018), pp. 1-8, https://doi.org/10.1016/j.gde.2018.05.00, 04.05.2021; Melinda A. Yang and Qiaomei Fu, "Insights into modern human prehistory using ancient genomes", in Trends in Genetics 34 (2018), pp. 184-196; João C. Teixeira and Alan Cooper, "Using hominin introgression to trace modern human dispersals", in Proceedings of the National Academy of Sciences of the United States of America 116 (2019), pp. 15327-15332; David L. Wilcox, "Genetic insights for human origins in Africa and for later Neanderthal contact", in Perspectives on Science and Christian Faith 66 (2014), pp. 140-153.
} 
of their genetic material from the Neanderthals. ${ }^{37}$ This introgression of Neanderthal DNA into modern human genome brought us many advantages, such as an improvement of our immune system $^{38}$ and an expansion of our genetic diversity, which had been drastically reduced in the course of emigration from Africa. ${ }^{39}$

This improvement of the immune system and expansion of genetic diversity was certainly necessary for the survival of the Homo sapiens who emigrated from Africa; because outside Africa, many unknown pathogens were threatening them. To acquire comparable genes through normal evolution would have taken a lot of time; and presumably this emigration would have been as unsuccessful as the previous emigrations of Homo sapiens from Africa. ${ }^{40}$ Without this interbreeding with the Neanderthal the emigration of Homo sapiens from Africa would probably not have lasted, and today there would be Homo sapiens only on the African continent.

\section{INFERENCES ABOUT THE CREATOR}

The consideration of different parts of scientific knowledge can lead to different ideas about the Creator of the universe, so it is important to look at the different parts together. The data given in the previous two chapters are an essential complement to what we know about the Creator from astronomy and physics.

Both the Kalam cosmological argument, ${ }^{41}$ which considers the beginning of the universe, and the already mentioned "fine-tuning" of the fundamental physical constants present very good arguments for the belief, that our universe was created by a transcendent

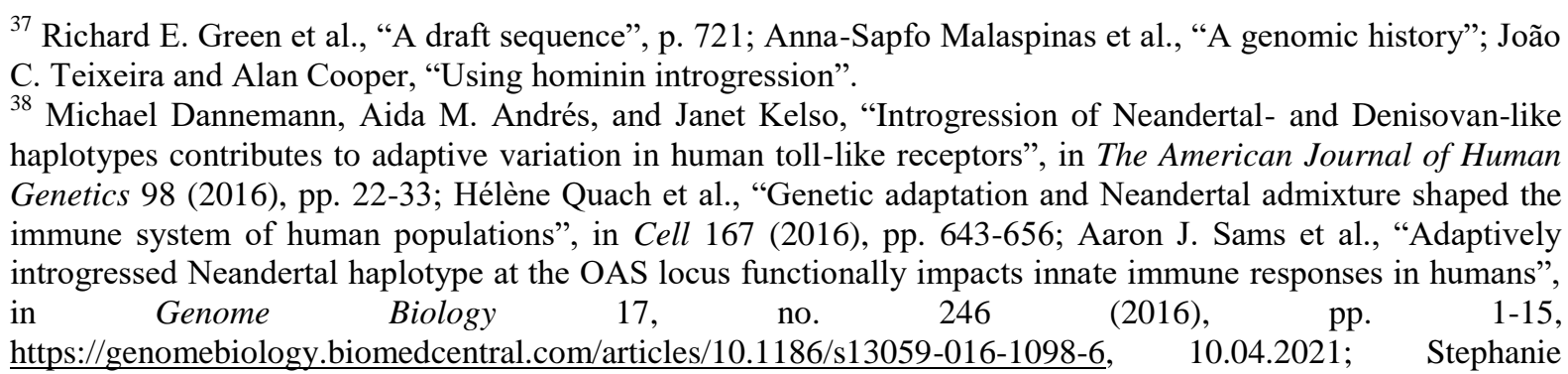
https://genomebiology.biomedcentral.com/articles/10.1186/s13059-016-1098-6, 10.04.2021; Stephanie Nature Reviews Genetics 18 (2017), pp. 659-674; Olga Dolgova and Oscar Lao, "Evolutionary and medical consequences of archaic introgression into modern human genomes", in Genes 9, no. 358 (2018), pp. 1-12, https://www.mdpi.com/2073-4425/9/7/358, 10.04.2021; Alexandre Gouy and Laurent Excoffier, "Polygenic patterns of adaptive introgression in modern humans are mainly shaped by response to pathogens", in Molecular Biology and Evolution 37 (2020), pp. 1420-1433.

${ }^{39}$ Eugene E. Harris, Ancestors in Our Genome, the New Science of Human Evolution, Oxford University Press, Oxford, 2015, p. 123; David C. Rinker et al., "Neanderthal introgression reintroduced functional ancestral alleles lost in Eurasian populations", in Nature Ecology \& Evolution 4 (2020), pp. 1332-1341.

${ }^{40}$ Huw S. Groucutt et al., "Rethinking the dispersal of Homo sapiens out of Africa", in Evolutionary Anthropology: Issues, News, and Reviews 24 (2015), pp. 149-164; Ryan J. Rabett, "The success of failed Homo sapiens dispersals out of Africa and into Asia”, in Nature Ecology \& Evolution 2 (2018), pp. 212-219.

${ }^{41}$ Paul Copan / William Lane Craig, (eds.), The Kalam Cosmological Argument, Volume 1: Philosophical Arguments for the Finitude of the Past, Bloomsbury Academic, London, 2019; Paul Copan / William Lane Craig, (eds.), The Kalam Cosmological Argument, Volume 2: Scientific Evidence for the Beginning of the Universe, Bloomsbury Academic, London, 2019; Andrew Loke, "Is an uncaused beginning of the universe possible? A response to recent naturalistic metaphysical theorizing", in Philosophia Christi 14 (2012), pp. 373393; Andrew Loke, God and Ultimate Origins. A Novel Cosmological Argument, Springer Nature, Cham, 2017; Peter J. Bussey, "God as first cause - a review of the Kalam argument", in Science \& Christian Belief 25 (2013), pp. 17-35; Richard Swinburne, Existence of God, pp. 133-152; James Goetz, "Theodicy, supreme providence, and semiclassical theism”, in Theology and Science 19 (2021), pp. 42-64. 
superior intelligence. However, about the Creator himself they give relatively little information:

- One can assume that the Creator is very generous, because he has created an immensely large universe. Modern astronomy has shown us that our Sun is one of hundreds of billions of suns in the Milky Way, and our Milky Way is only one of about 2 trillion galaxies in the entire universe. ${ }^{42}$

- From the "fine-tuning" of the fundamental physical constants one can conclude that the Creator has an interest in the creation of life in this universe. ${ }^{43}$

Very different ideas are compatible with this little information - e.g. also the idea of a divine watchmaker who leaves his universe to itself; for in the beginning he created the universe with fixed laws that determine its entire history. ${ }^{44}$

The indeterminacy of quantum physics refutes the idea of a deterministic universe. Quantum physics brings a first dimension of freedom to the universe. From this one can conclude that the Creator wants his creatures to have freedom. Moreover, quantum physics enables the Creator to intervene in this universe without violating the laws of nature. Nevertheless, the question must remain open whether the Creator intervenes in this universe at all, or whether he leaves it to itself. The question whether the Creator intervenes in this universe or not is very important to many people, because a Creator who intervenes is important for us, whereas many people are more or less indifferent to a Creator who does not intervene at all.

\subsection{Did the Creator intervene in the history of the Earth?}

The events of the Earth's history presented in the previous chapter can be seen as important indications for the assumption that the Creator actively intervened to promote the development of life - and especially intelligent life - on planet Earth.

It is possible for the most primitive forms of life to develop on a planet. From numerous experiments we know that it is plausible that the simplest forms of life develop by organizing abiotically formed organic substances, if certain circumstances are given and sufficient time are available. ${ }^{45}$ But what are the prerequisites for a diverse life to evolve, or

\footnotetext{
${ }^{42}$ Christopher J. Conselice et al., "The evolution of galaxy number density at $\mathrm{z}<8$ and its implications", in The Astrophysical Journal 830, no. 83 (2016), pp. 1-17, https://iopscience.iop.org/article/10.3847/0004637X/830/2/83/meta, 15.04.2021.

43 Joshua M. Moritz, "Big bang cosmology and christian theology", in Richard Gordon / Joseph Seckbach, (eds.), Theology And Science: From Genesis To Astrobiology, World Scientific, New Jersey: 2018, pp. 353-360.

${ }^{44}$ Egbert Giles Leigh Jr, "Does evolution compromise Christian faith? R. J. Asher's Evolution and Belief", in Evolution: Education and Outreach 6, no. 15 (2013), p. 2, http://www.evolution-outreach.com/content/6/1/15, 15.04.2021.

${ }^{45}$ Stanley L. Miller, “A production of amino acids under possible primitive earth conditions", in Science 117 (1953), pp. 528-529; Neil A. Campbell / Jane B. Reece, Biology, pp. 518-521; Scott Freeman / Jon C. Herron, Evolutionary analysis, pp. 616-636; Bernd M. Rode, Daniel Fitz, and Thomas Jakschitz, "The first steps of chemical evolution towards the origin of life", in Chemistry \& Biodiversity 4 (2007), pp. 2674-2702; Sean F. Jordan et al., "Promotion of protocell self-assembly from mixed amphiphiles at the origin of life", in Nature Ecology \& Evolution 3 (2019), pp. 1705-1714; Dirk U. Bellstedt, "The building blocks and origins of life", in HTS Teologiese Studies / Theological Studies 76 (2020), a6054, https://doi.org/10.4102/hts.v76i1.6054, 25.04.2021; Emily Boring, J. B. Stump, and Stephen Freeland, "Rethinking abiogenesis: part 1, continuity of life through time", in Perspectives on Science and Christian Faith 72 (2020), pp. 25-35; Ziwei Liu et al., "Harnessing chemical energy for the activation and joining of prebiotic building blocks", in Nature Chemistry 12 (2020), pp. 1-6; Christopher J. Butch et al., "Open questions in understanding life's origins", in Communications Chemistry 4, no. 11 (2021), pp. 1-4, https://doi.org/10.1038/s42004-021-00448-8, 12.05.2021.
} 
even for intelligent living beings to develop? In the previous chapter I listed four events that were of central importance for the development of life and mankind. Certainly there have been more events of vital importance in the course of Earth's history. But these four events in themselves are extraordinary and very unlikely, and their combination in that order is even more unlikely.

Let us begin with the first event, the Earth's collision with a Mars-sized body. How rare might such a thing happen? And how rare might it be that the results of such a catastrophe lead not to the permanent and complete uninhabitability of the planet, but to an improvement? The collision of the planets could have blown up both planets. Or the axial tilt of the Earth against the orbit of the Earth around the Sun would have become so large that extreme differences between the seasons and devastating storms would have hindered the development of life.

In the second event, the production of free oxygen, the time and extent of the release of oxygen was of extraordinary importance for the further development of life. And for the third and fourth events, too, the timing was of crucial importance.

How can it be that in the course of the Earth's history this sequence of events occurred at exactly the right time? Is life on this planet and humanity the random result of an extremely unlikely random chain of unlikely events that chanced to happen at exactly the right time? I cannot imagine that all this is just coincidence, because the probability of this is negligible. It is much more plausible to assume that the Creator of the universe deliberately intervened to promote the development of intelligent life.

However, one must admit that neither one nor the other interpretation can be proven.

We cannot prove that the Creator has NOT intervened here: Admittedly, we cannot see in any of the events that they contradict the laws of nature known to us. But this could also be because we do not know enough details about these events. Even if we knew at some point that they do not contradict any of the laws of nature, this would not mean that the Creator's deliberate intervention is impossible. For the Creator could also intervene without violating the laws of nature.

Neither can we prove that the Creator intervened here; for probability only says that it is extremely unlikely that this chain of events is accidental; but it does not say that it is impossible.

At this point we can only work with plausibilities, because objective proof is impossible. In this chain of unlikely events it is much more plausible to suppose an intervention of the Creator of the universe, than to suppose that this extremely unlikely chain of events happened by chance.

If the Creator has intervened in the history of the Earth to promote the evolution of (intelligent) life, then (intelligent) life has great significance for the Creator, and the consideration of the history and diversity of life in the previous chapters can give us important conclusions about the Creator.

\subsection{Characteristics of the Creator}

The diversity and history of life presented in the previous chapters allows numerous conclusions about the Creator of the universe, which, together with the Kalam cosmological argument, the "fine-tuning" of the fundamental physical constants and the indeterminacy of quantum physics, paint the following picture:

- It is important to the Creator that life can arise and develop in this universe. 
- The Creator gives freedom to his creation. A first fundamental dimension of freedom emerges from Heisenberg's uncertainty principle. What Heisenberg's uncertainty principle is for quantum physics, the evolution of living beings is for biology: a further dimension of freedom, of unpredictability, of uncontrollable dynamic growth arises in a structure determined by natural laws. This increase in freedom is closely linked to the increase in autonomy that Dalleur considers. ${ }^{46}$ This all culminates in the emergence of man through evolution. Man is the climax of evolution on our planet, because he can decide freely.

- This universe comprises an abundance that suggests an exuberant generosity of the Creator: It would have been enough for us if the Creator had created a single sun with a single planet and a small number of plant and animal species. However, the Creator created an entire universe of unimaginably many suns. On our small planet Earth there are probably 11 million different species of living beings today. And there were many more species in the course of Earth's history.

- Patience must be an important characteristic trait of the Creator; for he did not create directly a finished Earth and the life on it, including us humans, as it is now, but he has accompanied an evolutionary process lasting billions of years.

- The sequence of events necessary for the emergence and spread of life and Homo sapiens can be interpreted as the work of a Creator who uses causal links and seemingly random events to steer the course of his creation in the right direction. From this it can be concluded that the Creator actively intervened several times in the processes of this universe and probably still does so today.

- An interplay between an evolutionary process in which life unfolds, and seemingly random events that give this evolutionary process a new direction, becomes apparent. This interplay could be described with the image of a constant dialogue between the Creator and his creation. Life enters into the dialogue with the Creator by unfolding independently according to its own laws. From time to time, the Creator responds by intervening and then allowing life to follow its own laws again.

- From the exuberant generosity of the Creator, together with his great patience and his constant dialogue with creation, one can conclude that the Creator loves his creation very much. One could even go so far as to suppose that love is an important characteristic of the Creator.

The image that emerges from these puzzle pieces is anything but that of a divine watchmaker who leaves his universe to itself. An image of a Creator becomes recognisable, who always accompanies his creation and guides it by means of seemingly random events and - where necessary - intervenes correctively. This is a Creator who renews his creation again and again in a process of creation that is not yet complete. This is a Creator who has patience with his creation. In a constant dialogue with his creation, he travails and waits patiently until his creation has unfolded its full beauty in freedom. ${ }^{47}$ Comparable views have already been expressed by other authors. For example, Byrnes and Haught also characterise creation with words such as "process" and "novelty". ${ }^{48}$ Herce speaks of God accompanying

\footnotetext{
${ }^{46}$ Philippe Dalleur, "La possession du degré d'autonomie chez les vivants", in Scientia et Fides 3 (2015), pp. 115-138.

${ }^{47}$ John F. Haught, Deeper Than Darwin: The Prospect for Religion in the Age of Evolution, Westview Press, Boulder, CO, 2003, p. 80.

${ }^{48}$ W. Malcolm Byrnes, "Epigenetics, evolution, and us", in The National Catholic Bioethics Quarterly 3 (2003), pp. 489-500; John F. Haught, Deeper Than Darwin.
} 
evolution. ${ }^{49}$ Similar thoughts can also be found in Martínez Baigorri, Franklin, and Murphy as well as Boring, Stump, and Freeland. ${ }^{50}$

What in this universe is most valuable to the transcendent Creator? If an intelligent higher being has created the universe, it has a purpose. And to whom may his intention have been directed in a special way? Perhaps to the gas molecules and the stones that cannot think and feel and always obey only the laws of nature? Certainly not! Only the representatives of intelligent life can think, love, make free decisions and commune with him, the Creator. And here, on planet Earth, we, the human beings, are the intelligent life. From these considerations, it can be assumed that we humans have a special value for the Creator of the universe, because he can communicate with us. ${ }^{51}$ In logical consequence, we might assume that the Creator longs to communicate with us. From this point of view, human being's religiosity can be interpreted as a human trait, created and/or promoted by the Creator of the universe in the course of evolution, which shall prepare and/or enable the communication of human being with the Creator.

Let us dare to go one step further: we have seen that in the relationship between the Creator and his creation, dialogue is of central importance. Therefore, it is reasonable to suppose that the Creator is not a monolithic block, but that he himself is in some way engaged in an inner dialogue. The abundance and beauty of our universe could then be a faint reflection of the abundance and beauty of the Creator's inner dialogue.

\subsection{Identification of the Creator with the Judeo-Christian God}

It would go beyond the scope of this article to compare the characteristics of the Creator worked out here with what the various religions say on this subject. At this point, I will only try to compare the Creator with the Judeo-Christian God, because in my opinion the religious teachings of Christianity correspond best to what we have shown above.

- A central point of Judaism and Christianity is freedom. The central meaningful event of Judaism is the liberation from slavery in Egypt. Similarly, Christianity insists that Jesus Christ has rescued us from the slavery of sin.

- The exuberant generosity of the Creator is documented by the promise of eternal life in an exuberant fullness after biological death, which is the essential hope of Christianity.

- The fact that the Judeo-Christian God has much patience can be seen in the Bible in many places. I would particularly like to mention the slowly progressing selfrevelation of God, and the history of the people of Israel documented in the Old Testament.

- The Bible shows not only the great patience of the Judeo-Christian God, but also that he always tries to enter into a dialogue with his creatures. In both the Old Testament

\footnotetext{
${ }^{49}$ Rubén Herce, "Evolución y Creación, ¿qué nos puede aportar la controversia de auxiliis para entender su relación?", in Ildefonso Murillo, (ed.), Pensar y conocer a Dios en el siglo XXI, Diálogo Filosófico, Colmenar Viejo, 2016, p. 550.

${ }^{50}$ Martínez Baigorri, J. "La teología de la creación a la luz de la ciencia: Presente y futuro en la constante tarea de renovar la teología de la creación”, in Scientia et Fides 7 (2019), pp. 183-205; Franklin, P. "Understanding the beginning in light of the end: eschatological reflections on making theological sense of evolution", in Perspectives on Science and Christian Faith 66 (2014), pp. 154-70; George L. Murphy, "The nuts and bolts", pp. 53-55; Emily Boring, J. B. Stump, and Stephen Freeland, "Rethinking abiogenesis", p. 33.

${ }_{51}$ Paul M. Rosenblum, "Seeking purpose in creation and evolution: the agapic principle", in Theology and Science 18 (2020), pp. 86-98.
} 
and the New Testament, God repeatedly seeks man as a dialogue partner, in order to conduct a dialogue with him from You to You. An important goal of these dialogues is to lead people into ever greater abundance and freedom.

- The incarnation of Jesus Christ can be understood as the culmination of the dialogue between the Creator and his creation. Since man, as the crown of creation, evades dialogue with his Creator, God becomes man in order to make dialogue with man as easy as possible. The mission of Jesus is to let us participate in the exuberant fullness of God (John 10:10).

- The supposition expressed above that the Creator is not a monolithic block, but is himself in some way engaged in an inner dialogue, fits very well with the concept of a Trinitarian God that Christianity has. This belief that God consists of three persons who communicate with each other radically distinguishes Christianity from Judaism and Islam; for in both Judaism and Islam God is understood as a monolithic block.

- It has been noted that the Creator loves his creation very much, and it is supposed that love is an important characteristic of the Creator. Both are explicitly stated in the Bible about the Judeo-Christian God; in the New Testament it is even defined that God is love (Genesis 1:31; John 3:16; 1 John 4:8; 1 John 4:16).

\section{A CLOSER LOOK ON THREE IMPORTANT ASPECTS}

This essay presents an image of a Creator who patiently, in an evolutionary process lasting billions of years, leads his creation to ever greater freedom and abundance. This process can be described as a dialogue between the Creator and its creation. In the following I would like to counter two possible criticisms of this interpretation: 1) that the Creator might be timeless and 2) that evolution might be a directed process. Furthermore, at the end I will take a closer look at freedom, because it is very important in this context.

\subsection{Is the Creator of the universe timeless?}

Above I stated that the Creator is patient and in constant dialogue with his creation. This statement may meet with protest from some philosophers, because in Christian philosophy the prevailing opinion has been that God as the Creator of the universe is timeless. ${ }^{52}$ And with a timeless Creator it makes no sense to say that $\mathrm{He}$ is patient or that $\mathrm{He}$ participates in a progressive dialogue, since "progress" necessarily has a temporal component. This criticism can be refuted with the following arguments:

- Some modern Christian philosophers and theologians hold the view that God is not timeless, but that there is a kind of time with him. ${ }^{53}$

\footnotetext{
${ }^{52}$ R. T. Mullins, The End of the Timeless God, Oxford University Press, Oxford, 2016.

${ }^{53}$ See in particular: R. T. Mullins, The End of; Jon Paul Sydnor, "God is not eternal, nor are we: on the blessedness of being in time", in Process Studies 47 (2018), pp. 172-90; Richard A. Holland, God, Time, and the Incarnation, Wipf and Stock, Eugene, OR, 2012; Robert John Russell, Time in Eternity: Pannenberg, Physics, and Eschatology in Creative Mutual Interaction, University of Notre Dame Press, Notre Dame, IN, 2012. Furthermore: Antje Jackelén, Time \& Eternity: The Question of Time in Church, Science and Theology, Templeton Press, West Conshohocken, PA, 2005; Joseph Diekemper, "Eternity, knowledge, and freedom", in Religious Studies 49 (2013), pp. 45-64; Ted Peters, “Time in eternity and eternity in time”, in Jennifer Baldwin, (ed.), Embracing the Ivory Tower and Stained Glass Windows, Springer Nature Switzerland AG, Basel 2016 , pp. 3-12.
} 
- Already the Book of Genesis, the first book of the Bible, describes the JudeoChristian God as a God who is in relationship with his creatures. He is present and active in the world and interacts with his creatures. ${ }^{54}$

- God makes a historical journey with the people of Israel. In this way God reveals Himself to the people of Israel step by step more and more - from Abraham to Moses and the prophets to Jesus Christ.

- In many places in the Bible, God is expressly described as patient. ${ }^{55}$

- In Jesus Christ the transcendent God becomes man. What is decisive here is not only, that God, through his incarnation, engages in the temporality of our world, but also, that he carries this temporality into the innermost part of the Trinity of God through the resurrection and ascension of Jesus Christ. For in the ascension, Jesus Christ takes with him a risen human body that bears the wounds of the crucifixion (John 20:2529). The incarnation and resurrection of Jesus Christ not only mark a "before" and an "after" in this universe, but in the same way they mark a "before" and an "after" for the Trinitarian God.

\subsection{Is evolution a directed process?}

Another question worthy of discussion is: Is evolution a directed process in the sense of teleology with the aim of producing humans? This view is frequently held in the literature. ${ }^{56}$ What significance do mutations have there as undirected and random events?

If evolution were a directed process in the sense of teleology, I don't think it would make sense to say: "The Creator gives his creation time to develop autonomously." It is precisely because mutations are undirected and random events that a dimension of indeterminacy comes into evolution, which enables free and autonomous development. However, since there are numerous internal and external constraints that limit the scope of what is possible, it often seems as if the process of evolution is directed.

I am not claiming that the goal of biological evolution are humans, but I am claiming that under favourable conditions, one of the expected results of biological evolution is the emergence of intelligent life. This view is also held by Conway Morris and Barrigar. ${ }^{57}$

Mutations are undirected and random. Nonetheless, it does not follow that the visible results of biological evolution are undirected and random. Natural selection means that carriers of advantageous mutations have better chances than carriers of disadvantageous mutations. Which mutations are advantageous in a specific situation depends on the one hand

\footnotetext{
${ }^{54}$ Bruce C. Birch et al., A Theological Introduction to the Old Testament, Abingdon Press, Nashville, TN, 1999, p. 42.

55 See for example: Exodus 34:6; Numbers 14:18; Psalm 103:8; Nahum 1:3; Sirach 1:11; 2 Peter 3:9-15. In many cases the New International Version uses "slow to anger".

56 Johan De Smedt / Helen De Cruz, The Challenge of Evolution to Religion, Cambridge University Press, Cambridge, 2020, pp. 8-25; Gaven Kerr, "Design arguments and Aquinas's fifth way", in The Thomist: A Speculative Quarterly Review 82 (2018), pp. 447-471; Mariusz Tabaczek, "An Aristotelian account of evolution and the contemporary philosophy of biology", in The First Virtual International Conference on the Dialogue between Science and Theology: Cosmology, Life \& Anthropology, Ovidius University, Constanta, Romania, 2014, pp. 57-69; Mariusz Tabaczek, "Thomistic response to the theory of evolution: Aquinas on natural selection and the perfection of the universe", in Theology and Science 13 (2015), pp. 325-344.

57 Simon Conway Morris, Life's Solution: Inevitable Humans in a Lonely Universe, Cambridge University Press, Cambridge, 2003; Simon Conway Morris, "The predictability of evolution: glimpses into a postDarwinian world", in Naturwissenschaften 96 (2009), p. 1328; Chris Barrigar, "God's agape"; J. B. Stump, "Did God guide our evolution?", in Perspectives on Science and Christian Faith 72 (2020), p. 18.
} 
on the living being itself (genetic material, metabolism, body plan, etc.) and on the other hand on external factors (environmental conditions and interactions with other living beings). As a result, one can often observe certain trends in the evolution of a group of living beings:

- A classic example is the parallel development of the lens eye in vertebrates and molluscs. ${ }^{58}$ Conway Morris gives further examples of convergent evolution. ${ }^{59}$

- Another classic example is the phylogenetic evolution of horses. ${ }^{60}$ From the dogsized, forest-dwelling Hyracotherium to the horse Equus living today, the same evolutionary trends (reduction of lateral toes, adaptation of teeth to grazing and enlargement of the body) have been followed, as they always represented an evolutionary advantage.

- Another example is "Cope's rule", the trend of increasing body size within an evolutionary series. ${ }^{61}$

Just as the further development of the eye brings advantages in natural selection, the further development of the brain also brings selection advantages. However, there are limitations here due to the animal's body plan. For example, insects are very limited in their body size because they do not have lungs but breathe through tracheas. Reptiles do have lungs, but are poikilothermal animals, which also limits the development of the brain. If we then go into the evolutionary series of man to Australopithecus, we see that Australopithecus gave rise to two different lines: On the one hand Paranthropus, whose body specialised in hard plant foods and in which the brain remained small; and on the other hand Homo, who used tools and in which the brain became larger. ${ }^{62}$

Increasing intelligence is not the only possible solution to the challenges of natural selection, but it is one possible solution. Therefore, through random mutations and natural selection, intelligent beings can be created without having to adopt any teleology or alignment to a goal. So far, I speak as a scientist who ignores all transcendence. From now on, I speak as a believer: I believe that the Creator of the universe uses these natural processes, which are not goal-oriented, to achieve his goals, because he knows that these processes serve his goals, although they are not goal-oriented. Furthermore, I see the abovementioned extraordinary events in the history of the Earth and cannot believe that it is pure coincidence that they happened at exactly the right time. That is why I do not interpret these events as coincidental, but I see in them the work of the Creator of the universe, who intervenes in the history of the Earth through these events, in order to influence the course of Earth history and evolution.

\footnotetext{
${ }^{58}$ Neil A. Campbell / Jane B. Reece, Biology, p. 477; Scott Freeman / Jon C. Herron, Evolutionary analysis, pp. 97-98; Ulrich Kutschera and Karl J. Niklas, "The modern theory of biological evolution: an expanded synthesis", in Naturwissenschaften 91 (2004), p. 272; Bradford McCall, "The God of chance and purpose", in Theology and Science 17 (2019), pp. 133-142.

${ }^{59}$ Simon Conway Morris, Life's Solution; Simon Conway Morris, "The predictability of evolution".

${ }^{60}$ Neil A. Campbell / Jane B. Reece, Biology, pp. 480-481.

${ }^{61}$ David W. E. Hone and Michael J. Benton, "The evolution of large size: how does Cope's Rule work?", in Trends in Ecology \& Evolution 20 (2005), pp. 4-6; Joel G. Kingsolver and David W. Pfennig, "Individual-level selection as a cause of Cope's rule of phyletic size increase", in Evolution 58 (2004), pp. 1608-1612; Noel A. Heim et al., "Cope's rule in the evolution of marine animals", in Science 347 (2015), pp. 867-870; Andreas May, "Statistics on Thamnopora (Tabulata, Devonian)", in Boletín de la Real Sociedad Española de Historia Natural (Sección Geológica) 91 (1997), p. 222; Andreas May, "Statistische Untersuchungen an der tabulaten Koralle Thamnopora (Anthozoa, Devon)", in Geologica et Palaeontologica 32 (1998), p. 147.

${ }^{62}$ Friedemann Schrenk and Timothy G. Bromage, “Origins of hominin”, pp. 412-414.
} 
I cannot and do not want to exclude the possibility that the Creator of the universe has in some other way intervened in Earth history and evolution, in order to achieve that intelligent life arises and spreads on Earth. This kind of influence can have been quite different. For example, various modern authors have argued that God could use the indeterminacy of quantum physics to intervene in this immanent universe without coming into conflict with any laws of nature. ${ }^{63}$ Ulanowicz looks at other natural processes and sees also there possibilities how God could intervene without coming into conflict with any natural laws. ${ }^{64}$ The chaos theory also offers space for an inconspicuous intervention of God. ${ }^{65}$

In this context, I would like to point out that according to Brink, Ridder, and Woudenberg the randomness of mutations is compatible with the divine guidance of the evolutionary process. ${ }^{66}$ And McCall works out that God does not determine the outcome of every scientifically random event, but that he instead controls randomness by setting wide limits. ${ }^{67}$ Conway Morris uses convergent developments to show how narrow these limits are that the evolutionary process has. ${ }^{68}$

\subsection{Freedom}

As noted above, the freedom of his creatures is very important to God, the Creator of this universe. From the very beginning, He prepared everything so that we humans have the greatest possible freedom, starting with the indeterminacy of quantum physics and other natural processes. ${ }^{69}$ This is not yet freedom in the sense of a conscious decision, but it is a step in this direction. Then God let all living beings arise through biological evolution, which led to further degrees of freedom. Presumably, God chose the way of evolution to ensure that we, the intelligent living beings, have the perfect freedom to believe in Him or to let it be, as well as to love Him, ignore Him or reject Him. This freedom is in fact a necessary condition to be able to love Him freely. Humans are the crown of creation on Earth; for only humans are able to accept or refuse God's love in conscious free decision. From this point of view, we can accept all the suffering that has occurred in the context of evolution as part of God's very good creation. ${ }^{70}$ Since God has chosen to create the exuberant abundance of life and us

\footnotetext{
${ }^{63}$ Charles H. Townes, "Basic puzzles“; Marcos Ruiz Soler and Ignacio Núñez de Castro, "La kénosis del Dios”, pp. 61-62; George L. Murphy, "The nuts and bolts", p. 57; Daekyung Jung, "The RNA world"; Ted Peters, "Science and Religion", pp. 31-34; Robert John Russell, Cosmology from Alpha; Robert John Russell, "What we've learned".

${ }^{64}$ Robert E. Ulanowicz, "The universal laws of physics", in Robert John Russell and Joshua M. Moritz (eds.), God's Providence and Randomness in Nature: Scientific and Theological Perspectives, Templeton Press, West Conshohocken, PA, 2019, pp. 69-84.

${ }^{65}$ John Polkinghorne, Science and Christian Belief: Theological Reflections of a Bottom-up Thinker, SPCK Publishing, London, 1994; Ignacio Silva, "John Polkinghorne on divine action: a coherent theological evolution", in Science \& Christian Belief 24 (2012), pp. 20-22.

${ }^{66}$ Gijsbert van den Brink, Jeroen de Ridder, and René van Woudenberg, "The epistemic status of evolutionary theory", in Theology and Science 15 (2017), p. 468.

${ }^{67}$ Bradford McCall, "The God of chance".

${ }^{68}$ Simon Conway Morris, Life's Solution; Simon Conway Morris, "The predictability of evolution".

${ }^{69}$ Charles H. Townes, "Basic puzzles“, p. 130; George F. R. Ellis, "Necessity, purpose"; Ted Peters, "Contingency and freedom", pp. 278-280; Robert E. Ulanowicz, "The universal laws".

${ }^{70}$ Denis O. Lamoureux, "Toward an evangelical evolutionary theodicy", in Theology and Science 18 (2020), pp. 12-30; Keith B. Miller, "And God saw that it was good: death and pain in the created order", in Perspectives on Science and Christian Faith 63 (2011), p. 90; Genesis 1:31.
} 


\section{International Journal of Theology, Philosophy and Science \\ No. 8, Year 5/2021 \\ https://ijtps.com/ \\ ISSN 2601-1697, ISSN-L 2601-1689}

through evolution, natural disasters, physical suffering, illness and death are not only unavoidable concomitants, but necessary instruments of creation through evolution. ${ }^{71}$

The Bible documents how much God strives to lead people to freedom: In the Old Testament, God acted exemplarily on the people of Israel by liberating them twice: on the one hand, the liberation from slavery in Egypt; on the other hand, the liberation from the Babylonian exile. Christianity teaches that the ultimate and comprehensive liberation of man is the liberation from the slavery of sin and death. This liberation took place through the death of Jesus Christ on the cross. Jesus Christ entirely voluntarily took upon himself the death on the cross. ${ }^{72}$ At the same time, he was always completely obedient to God the Father. Through his loving obedience, Jesus Christ liberated us comprehensively.

Why is our freedom so extremely important to God? The only plausible answer is love: God wants us to be able to respond to His love for us freely and without constraint. God does not want any will-less slaves, because the entire universe already obeys Him unconditionally; God is looking for a "you", to whom He can be "You" and who can participate in His Trinitarian community of love.

If we wish to respond adequately to this love that God has for us, we might try to use all our freedom to give all our love and all our capacity for obedience to God. The highest possible act of freedom and love that we can do, is to give our freedom back to God as loving obedience. By giving back our freedom to God-Son as loving obedience, our own freedom does not diminish; on the contrary, it increases: the more we obey Jesus Christ, the freer we become, and we share in the freedom of the children of God. ${ }^{73}$ This is an important paradox of Christianity: obeying Jesus Christ will set us free.

\section{CONCLUSION}

In this essay I tried to draw conclusions about the Creator of the universe from the evolution and diversity of life and from the Earth's history. Thereby, my essay differs fundamentally from many papers and books that have been written on the subject of evolution and Christianity; because normally these works start from a Christian world-view and thus try to interpret the scientific findings. Here, exactly the opposite way is taken. This opens up completely new possibilities of dialogue with the natural sciences; from now on, one cannot claim that an alien interpretation is imposed on the scientific insights, but the interpretations result naturally from the scientific observations.

It was possible to sketch an image of a Creator who patiently, in an evolutionary process lasting billions of years, leads his creation to ever greater freedom and abundance. The characteristics of the Creator that are worked out here fit very well with the JudeoChristian God.

When comparing the relationship of the Creator of the universe to his creation with the relationship of the Judeo-Christian God to human beings, we observe the same pattern:

\footnotetext{
${ }^{71}$ Marcos Ruiz Soler and Ignacio Núñez de Castro, "La kénosis del Dios”, p. 63; Miller, K.B. "Natural hazards: challenges to the creation mandate of dominion?", in Perspectives on Science and Christian Faith 53 (2001), pp. 184-187 (p. 187).

${ }_{72}$ John 10:17-18; Philippians 2:6-8; Lohmann, F. "God's freedom: free to be bound", in Modern Theology 34 (2018), pp. 368-385.

${ }^{73}$ Romans 8:21; Highfield, R. God, Freedom and Human Dignity: Embracing a God-Centered Identity in a MeCentered Culture, InterVarsity Press, Westmont, 2012, pp. 181-190; Pope Francis, „The Freedom of God's Children, Thursday, 4 July 2013', The Holy See, http://www.vatican.va/content/francesco/en/cotidie/2013/documents/papa-francescocotidie 20130704 freedom-children.html, 12.05.2021.
} 
the Creator is in constant dialogue with his creation. He gives his creation time to develop autonomously and intervenes from time to time to correct the direction of development. The aim of the Creator's intervention is to lead his creation to ever greater abundance and freedom.

In retrospect, it is remarkable how largely the results of this essay agree with interpretations that start from a Christian world-view. Nevertheless, the reversal of approach has yielded important insights:

- God's exuberant generosity and extraordinary patience become much more apparent in this essay than in other reflections.

- For God, the freedom of his creation is a very important good.

- Much more clearly than in other papers, it is shown that evolution is a dialogue between the Creator and His creation.

- There is a wide discussion in the literature about whether and how God intervenes in evolution. Concrete examples of God's intervention in the Earth's history are shown here.

Finally, the essay debunks two possible criticisms. It elaborates that there are good reasons to assume that the Creator of the universe is not timeless, but that there is a kind of time with him. Evolution is interpreted as an undirected process that, among other things, also leads to intelligent living beings. The intelligent life forms that have come into being through evolution have the freedom to decide for or against the love of the Creator for them.

\section{BIBLIOGRAPHY:}

[1] Alcott, Lewis J., Mills, Benjamin J. W., and Poulton, Simon W., "Stepwise Earth oxygenation is an inherent property of global biogeochemical cycling", in Science 366 (2019), pp. 1333-1337.

[2] Alemseged, Zeresenay, et al., "Fossils from Mille-Logya, Afar, Ethiopia, elucidate the link between Pliocene environmental changes and Homo origins", in Nature Communications 11, no. 2480 (2020), pp. 1-12, https://doi.org/10.1038/s41467-020-16060-8, 03.05.2021.

[3] Andel, Tjeerd H. van, New Views on an Old Planet: A History of Global Change, 2nd ed., Cambridge University Press, Cambridge, 1994.

[4] Balter, Vincent, et al., "Evidence for dietary change but not landscape use in South African early hominins“, in Nature 489 (2012), pp. 558-560.

[5] Barrigar, Chris, "God's agape/probability design for the universe", in Perspectives on Science and Christian Faith 70 (2018), pp. 161-175.

[6] Barrow, John D. / Tipler, Frank J., The Anthropic Cosmological Principle, Oxford University Press, Oxford, 1988.

[7] Bellstedt, Dirk U., "The building blocks and origins of life", in HTS Teologiese Studies / Theological Studies 76 (2020), a6054, https://doi.org/10.4102/hts.v76i1.6054, 25.04.2021.

[8] Betts, Holly C., et al., "Integrated genomic and fossil evidence illuminates life's early evolution and eukaryote origin", in Nature Ecology \& Evolution 2 (2018), pp. 1556-1562.

[9] Birch, Bruce C., et al., A Theological Introduction to the Old Testament, Abingdon Press, Nashville, TN, 1999.

[10] Boring, Emily, Stump, J. B., and Freeland, Stephen, "Rethinking abiogenesis: part 1, continuity of life through time", in Perspectives on Science and Christian Faith 72 (2020), pp. 25-35.

[11]Bradley, Walter L., "The fine tuning of the universe: evidence for the existence of God?", in Perspectives on Science and Christian Faith 70 (2018), pp. 147-160.

[12] Brink, Gijsbert van den, Ridder, Jeroen de, and Woudenberg, René van, "The epistemic status of evolutionary theory", in Theology and Science 15 (2017), pp. 454-472.

[13] Butch, Christopher J., et al., "Open questions in understanding life's origins", in Communications Chemistry 4, no. 11 (2021), pp. 1-4, https://doi.org/10.1038/s42004-021-00448-8, 12.05.2021.

[14] Bussey, Peter J., "God as first cause - a review of the Kalam argument", in Science \& Christian Belief 25 (2013), pp. 17-35. 
[15] Byrnes, W. Malcolm, "Epigenetics, evolution, and us", in The National Catholic Bioethics Quarterly 3 (2003), pp. 489-500.

[16] Cai, Jing, et al., "The genome sequence of the orchid Phalaenopsis equestris", in Nature genetics 47 (2015), pp. 65-72.

[17] Campbell, Neil A. / Reece, Jane B., Biology, 6th ed., Pearson Education, San Francisco, 2002.

[18] Canup, Robin M., and Asphaug, Erik, "Origin of the Moon in a giant impact near the end of the Earth's formation", in Nature 412 (2001), pp. 708-712.

[19] Catling, David C., and Zahnle, Kevin J., "The Archean atmosphere", in Science Advances 6, no. eaax1420 (2020), pp. 1-16, https://advances.sciencemag.org/content/6/9/eaax1420, 20.04.2021.

[20] Chapman, Arthur D., Numbers of Living Species in Australia and the World, 2nd ed., Canberra, Australia, 2009.

[21] Chiarenza, Alfio Alessandro, et al., "Asteroid impact, not volcanism, caused the end-Cretaceous dinosaur extinction", in Proceedings of the National Academy of Sciences of the United States of America 117 (2020), pp. 17084-17093.

[22] Conselice, Christopher J., et al., "The evolution of galaxy number density at $\mathrm{z}<8$ and its implications", in The Astrophysical Journal 830, no. 83 (2016), pp. 1-17, https://iopscience.iop.org/article/10.3847/0004-637X/830/2/83/meta, 15.04.2021.

[23] Conway Morris, Simon, Life's Solution: Inevitable Humans in a Lonely Universe, Cambridge University Press, Cambridge, 2003.

[24] Conway Morris, Simon, "The predictability of evolution: glimpses into a post-Darwinian world", in Naturwissenschaften 96 (2009), pp. 1313-1337.

[25]Copan, Paul / Craig, William Lane, (eds.), The Kalam Cosmological Argument, Volume 1: Philosophical Arguments for the Finitude of the Past, Bloomsbury Academic, London, 2019.

[26] Copan, Paul / Craig, William Lane, (eds.), The Kalam Cosmological Argument, Volume 2: Scientific Evidence for the Beginning of the Universe, Bloomsbury Academic, London, 2019.

[27] Dalleur, Philippe "La possession du degré d'autonomie chez les vivants", in Scientia et Fides 3 (2015), pp. 115-138.

[28] Dannemann, Michael, Andrés, Aida M., and Kelso, Janet, "Introgression of Neandertal- and Denisovan-like haplotypes contributes to adaptive variation in human toll-like receptors", in The American Journal of Human Genetics 98 (2016), pp. 22-33.

[29] Dannemann, Michael, and Racimo, Fernando, "Something old, something borrowed: admixture and adaptation in human evolution", in Current Opinion in Genetics \& Development 53 (2018), pp. 1-8, https://doi.org/10.1016/j.gde.2018.05.009, 12.05.2021.

[30] De Smedt, Johan / De Cruz, Helen, The Challenge of Evolution to Religion, Cambridge University Press, Cambridge, 2020.

[31] Diekemper, Joseph, "Eternity, knowledge, and freedom", in Religious Studies 49 (2013), pp. 45-64.

[32] Dolgova, Olga, \& Lao, Oscar, "Evolutionary and medical consequences of archaic introgression into modern human genomes", in Genes 9, no. 358 (2018), pp. 1-12, https://www.mdpi.com/20734425/9/7/358, 10.04.2021.

[33] $\mathrm{Du}$, Andrew, et al., "Statistical estimates of hominin origination and extinction dates: A case study examining the Australopithecus anamensis-afarensis lineage", in Journal of Human Evolution 138, no. 102688 (2020), pp. 1-13, https://doi.org/10.1016/j.jhevol.2019.102688, 30.04.2021.

[34] Ellis, George F. R., "Necessity, purpose, and chance", in Robert John Russell and Joshua M. Moritz (eds.), God's Providence and Randomness in Nature: Scientific and Theological Perspectives, Templeton Press, West Conshohocken, PA, 2019, pp. 21-68.

[35] Emerling, Christopher A., Delsuc, Frédéric, and Nachman, Michael W., "Chitinase Genes (CHIAs) provide genomic footprints of a post-Cretaceous dietary radiation in placental mammals", in $\begin{array}{llllll}\text { Science Advances } 4, \quad \text { no. ear6478 (2018), pp. } & \text { 1-10, }\end{array}$ https://advances.sciencemag.org/content/4/5/eaar6478, 20.04.2021.

[36] Faries, Dillard W., "A personal God, chance, and randomness in quantum physics", in Perspectives on Science and Christian Faith 66 (2014), pp. 13-22.

[37] Franklin, Patrick,"Understanding the beginning in light of the end: eschatological reflections on making theological sense of evolution", in Perspectives on Science and Christian Faith 66 (2014), pp. 154-70.

[38] Freeman, Scott / Herron, Jon C., Evolutionary analysis, 3rd ed., Pearson Education, Upper Saddle River, NJ, 2003. 
[39] Fu, Qiaomei, et al., “A revised timescale for human evolution based on ancient mitochondrial genomes", in Current Biology 23 (2013), pp. 553-559.

[40] Fu, Qiaomei, et al., "Genome sequence of a 45,000-year-old modern human from western Siberia", in Nature 514 (2014), pp. 445-449.

[41] Gammie, Charles F., Liao, Wei-Ting, and Ricker, Paul M., "A hot big bang theory: magnetic fields and the early evolution of the protolunar disk", in The Astrophysical Journal 828 (2016), pp. 1-9, https://iopscience.iop.org/article/10.3847/0004-637X/828/1/58/meta, 28.04.2021.

[42] Glass, David H., and McCartney, Mark, "Explaining and explaining away in science and religion", in Theology and Science 12 (2014), pp. 338-361.

[43] Goetz, James, "Theodicy, supreme providence, and semiclassical theism", in Theology and Science 19 (2021), pp. 42-64.

[44] Gouy, Alexandre, \& Excoffier, Laurent, "Polygenic patterns of adaptive introgression in modern humans are mainly shaped by response to pathogens", in Molecular Biology and Evolution 37 (2020), pp. 1420-1433.

[45] Green, Richard E., et al., "A draft sequence of the Neandertal genome”, in Science 328 (2010), pp. 710-722.

[46] Groucutt, Huw S., et al., "Rethinking the dispersal of Homo sapiens out of Africa", in Evolutionary Anthropology: Issues, News, and Reviews 24 (2015), pp. 149-164.

[47] Halliday, Alex N., "Terrestrial accretion rates and the origin of the Moon", in Earth and Planetary Science Letters 176 (2000), pp. 17-30.

[48] Halliday, Thomas John Dixon, Upchurch, Paul, and Goswami, Anjali, "Eutherians experienced elevated evolutionary rates in the immediate aftermath of the Cretaceous-Palaeogene mass extinction", in Proceedings of the Royal Society B 283, no. 20153026 (2016), pp. 1-8, https://doi.org/10.1098/rspb.2015.3026, 11.05.2021.

[49] Harris, Eugene E., Ancestors in Our Genome, the New Science of Human Evolution, Oxford University Press, Oxford, 2015.

[50] Haught, John F., Deeper Than Darwin: The Prospect for Religion in the Age of Evolution, Westview Press, Boulder, CO, 2003.

[51] Heim, Noel A., et al., "Cope's rule in the evolution of marine animals", in Science 347 (2015), pp. 867870.

[52] Herce, Rubén, "Evolución y Creación, ¿qué nos puede aportar la controversia de auxiliis para entender su relación?", in Ildefonso Murillo, (ed.), Pensar y conocer a Dios en el siglo XXI, Diálogo Filosófico, Colmenar Viejo, 2016, pp. 543-551.

[53] Herwartz, Daniel, et al., "Identification of the giant impactor Theia in lunar rocks", in Science 344 (2014), pp. 1146-1150.

[54] Highfield, Ron, God, Freedom and Human Dignity: Embracing a God-Centered Identity in a MeCentered Culture, InterVarsity Press, Westmont, 2012.

[55] Holland, Richard A., God, Time, and the Incarnation, Wipf and Stock, Eugene, OR, 2012.

[56] Hone, David W. E., and Benton, Michael J., "The evolution of large size: how does Cope's Rule work?", in Trends in Ecology \& Evolution 20 (2005), pp. 4-6.

[57] Jablonski, David, "Extinctions: A paleontological perspective", in Science 253 (1991), pp. 754-757.

[58] Jackelén, Antje, Time \& Eternity: The Question of Time in Church, Science and Theology, Templeton Press, West Conshohocken, PA, 2005.

[59] Jordan, Sean F., et al., "Promotion of protocell self-assembly from mixed amphiphiles at the origin of life", in Nature Ecology \& Evolution 3 (2019), pp. 1705-1714.

[60] Jung, Daekyung, "The RNA world and divine action in and through quantum mechanics", in Theology and Science 16 (2018), pp. 498-519.

[61]Kerr, Gaven, "Design arguments and Aquinas's fifth way", in The Thomist: A Speculative Quarterly Review 82 (2018), pp. 447-471.

[62] Kingsolver, Joel G., and Pfennig, David W., "Individual-level selection as a cause of Cope's rule of phyletic size increase", in Evolution 58 (2004), pp. 1608-1612.

[63] Knoll, Andrew H., and Nowak, Martin A., "The timetable of evolution", in Science Advances 3, no. e1603076 (2017), pp. 1-13, https://advances.sciencemag.org/content/3/5/e1603076, 24.04.2021

[64] Kojonen, Rope, "Natural theology in evolution: a review of critiques and changes", in European Journal for Philosophy of Religion 9 (2017), pp. 83-117.

[65] Kring, David A., "The Chicxulub impact event and its environmental consequences at the CretaceousTertiary boundary”, in Palaeogeography, Palaeoclimatology, Palaeoecology 255 (2007), pp. 4-21. 
[66] Kutschera, Ulrich, and Niklas, K.J., "The modern theory of biological evolution: an expanded synthesis", in Naturwissenschaften 91 (2004), pp. 255-276.

[67]Lamoureux, Denis O., "Toward an evangelical evolutionary theodicy", in Theology and Science 18 (2020), pp. 12-30.

[68]Leigh, Egbert Giles, Jr, "Does evolution compromise Christian faith? R. J. Asher's Evolution and Belief", in Evolution: Education and Outreach 6, no. 15 (2013), pp. 1-7, http://www.evolutionoutreach.com/content/6/1/15, 15.04.2021.

[69] Liu, Ziwei, et al., "Harnessing chemical energy for the activation and joining of prebiotic building blocks", in Nature Chemistry 12 (2020), pp. 1-6.

[70] Lohmann, Friedrich, "God's freedom: free to be bound", in Modern Theology 34 (2018), pp. 368-385.

[71] Loke, Andrew, "Is an uncaused beginning of the universe possible? A response to recent naturalistic metaphysical theorizing", in Philosophia Christi 14 (2012), pp. 373-393.

[72] Loke, Andrew, God and Ultimate Origins. A Novel Cosmological Argument, Springer Nature, Cham, 2017.

[73] Malaspinas, Anna-Sapfo, et al., "A genomic history of Aboriginal Australia”, in Nature 538 (2016), pp. 207-214.

[74] Maor, Roi, et al., "Temporal niche expansion in mammals from a nocturnal ancestor after dinosaur extinction", in Nature Ecology \& Evolution 1 (2017), pp. 1889-1895.

[75] Marciniak, Stephanie, and Perry, George H., "Harnessing ancient genomes to study the history of human adaptation", in Nature Reviews Genetics 18 (2017), pp. 659-674.

[76] Martínez Baigorri, Javier, "La teología de la creación a la luz de la ciencia: Presente y futuro en la constante tarea de renovar la teología de la creación", in Scientia et Fides 7 (2019), pp. 183-205.

[77] Mawson, Tim J., "Explaining the fine tuning of the universe to us and the fine tuning of us to the universe", in Royal Institute of Philosophy Supplements 6 (2011), pp. 25-50.

[78] May, Andreas, "Statistics on Thamnopora (Tabulata, Devonian)", in Boletín de la Real Sociedad Española de Historia Natural (Sección Geológica) 91 (1997), pp. 217-230.

[79] May, Andreas, "Statistische Untersuchungen an der tabulaten Koralle Thamnopora (Anthozoa, Devon)", in Geologica et Palaeontologica 32 (1998), pp. 141-159.

[80] McCall, Bradford, "The God of chance and purpose", in Theology and Science 17 (2019), pp. 133-142.

[81]McGrath, Alister E., A Fine-Tuned Universe: The Quest for God in Science and Theology, Westminster John Knox Press, London, 2009.

[82] Meredith, Robert W., et al., "Impacts of the Cretaceous terrestrial revolution and KPg extinction on mammal diversification", in Science 334 (2011), pp. 521-524.

[83] Miller, Keith B., "Natural hazards: challenges to the creation mandate of dominion?", in Perspectives on Science and Christian Faith 53 (2001), pp. 184-187.

[84] Miller, Keith B., "And God saw that it was good: death and pain in the created order", in Perspectives on Science and Christian Faith 63 (2011), pp. 85-94.

[85] Miller, Stanley L., "A production of amino acids under possible primitive earth conditions", in Science 117 (1953), pp. 528-529.

[86] Molinaro, Ludovica, and Pagani, Luca, "Human evolutionary history of Eastern Africa", in Current Opinion in Genetics \& Development 53 (2018), pp. 134-139.

[87] Mora, Camilo, et al., "How many species are there on earth and in the ocean?", in PLoS Biology 9, no. e1001127 (2011), pp. 1-8, https://doi.org/10.1371/journal.pbio.1001127, 06.05.2021.

[88] Moritz, Joshua M., "Big bang cosmology and christian theology", in Richard Gordon / Joseph Seckbach, (eds.), Theology And Science: From Genesis To Astrobiology, World Scientific, New Jersey: 2018, pp. 345-372.

[89] Mosterín, Jesús, “Anthropic explanations in cosmology", in Petr Hájek, Luis Valdés-Villanueva, and Dag Westerståhl (eds.) Logic, Methodology and Philosophy of Science: Proceedings of the Twelfth International Congress, College Publications, London, 2004, pp. 441-472.

[90] Mullins, R.T., The End of the Timeless God, Oxford University Press, Oxford, 2016.

[91] Murphy, George L., "The nuts and bolts of creation", in Perspectives on Science and Christian Faith 70 (2018), pp. 48-59.

[92] Nutman, Allen P., et al., "Rapid emergence of life shown by discovery of 3,700-million-year-old microbial structures", in Nature 537 (2016), pp. 535-538.

[93] O'Leary, Maureen A., et al., "The placental mammal ancestor and the post-K-Pg radiation of placentals", in Science 339 (2013), pp. 662-667. 
[94] Pagani, Luca, et al., "Tracing the route of modern humans out of Africa by using 225 human genome sequences from Ethiopians and Egyptians", in The American Journal of Human Genetics 96 (2015), pp. 986-991.

[95] Peters, Ted, "Time in eternity and eternity in time", in Jennifer Baldwin, (ed.), Embracing the Ivory Tower and Stained Glass Windows, Springer Nature Switzerland AG, Basel 2016, pp. 3-12.

[96] Peters, Ted, "Science and Religion: Ten Models of War, Truce, and Partnership", in Theology and Science 16 (2018), pp. 11-53.

[97] Peters, Ted, "Contingency and freedom in brains and selves", in Robert John Russell and Joshua M. Moritz (eds.), God's Providence and Randomness in Nature: Scientific and Theological Perspectives, Templeton Press, West Conshohocken, PA, 2019, pp. 261-288.

[98] Polkinghorne, John, Science and Christian Belief: Theological Reflections of a Bottom-up Thinker, SPCK Publishing, London, 1994.

[99] Pope Francis, „The Freedom of God's Children, Thursday, 4 July 2013', The Holy See, http://www.vatican.va/content/francesco/en/cotidie/2013/documents/papa-francescocotidie 20130704 freedom-children.html, 12.05.2021.

[100] Press, Frank / Siever, Raymond, Understanding Earth, 3rd ed.,W. H. Freeman and Company, New York, 2000.

[101] Quach, Hélène, et al., "Genetic adaptation and Neandertal admixture shaped the immune system of human populations”, in Cell 167 (2016), pp. 643-656.

[102] Rabett, Ryan J., "The success of failed Homo sapiens dispersals out of Africa and into Asia", in Nature Ecology \& Evolution 2 (2018), pp. 212-219.

[103] Redfern, Martin, 50 Schlüsselideen Erde, Quercus Books, London 2014.

[104] Rinker, David C., et al., "Neanderthal introgression reintroduced functional ancestral alleles lost in Eurasian populations", in Nature Ecology \& Evolution 4 (2020), pp. 1332-1341.

[105] Rode, Bernd M., Fitz, Daniel, and Jakschitz, Thomas "The first steps of chemical evolution towards the origin of life", in Chemistry \& Biodiversity 4 (2007), pp. 2674-2702.

[106] Rödder, Gerhard, Ziegler, Fred-Karsten, and Falk, Eberhard, "Wie viele Arten? Der Stand der Forschung gegen Ende des Jahrhunderts", in Paläontologische Zeitschrift 67 (1993), pp. 215-222.

[107] Rosenblum, Paul M., "Seeking purpose in creation and evolution: the agapic principle", in Theology and Science 18 (2020), pp. 86-98.

[108] Ruiz Soler, Marcos, and Núñez de Castro, Ignacio, "La kénosis del Dios trinitario: reflexiones desde la teología de la naturaleza", in Estudios Eclesiásticos, Revista de investigación e información teológica y canónica 92, no. 360, (2017), pp. 53-94.

[109] Rumble, Douglas; et al., "The oxygen isotope composition of earth's oldest rocks and evidence of a terrestrial magma ocean", in Geochemistry, Geophysics, Geosystems 14 (2013), pp. 1929-1939.

[110] Russell, Robert John, Cosmology from Alpha to Omega: The Creative Mutual Interaction of Theology and Science, Fortress Press, Minneapolis, 2008.

[111] Robert John, Time in Eternity: Pannenberg, Physics, and Eschatology in Creative Mutual Interaction, University of Notre Dame Press, Notre Dame, IN, 2012.

[112] Russell, Robert John, "What we've learned from quantum mechanics about noninterventionist objective divine action in nature - and its remaining challenges", in Robert John Russell and Joshua M. Moritz (eds.), God's Providence and Randomness in Nature: Scientific and Theological Perspectives, Templeton Press, West Conshohocken, PA, 2019, pp. 133-172.

[113] Sams, Aaron J., et al., "Adaptively introgressed Neandertal haplotype at the OAS locus functionally impacts innate immune responses in humans", in Genome Biology 17, no. 246 (2016), pp. 1-15, https://genomebiology.biomedcentral.com/articles/10.1186/s13059-016-1098-6, 10.04.2021.

[114] Schrenk, Friedemann, and Bromage, Timothy G., "Origins of hominin biocultural diversity", in Nicole Rupp et al. (eds.), Winds of Change: Archaeological Contributions in Honour of Peter Breunig, Verlag Dr. Rudolf Habelt, Bonn, 2017, pp. 409-419.

[115] Silva, Ignacio, "John Polkinghorne on divine action: a coherent theological evolution", in Science \& Christian Belief 24 (2012), pp. 19-30.

[116] Siniscalchi, Glenn, "Fine-tuning, atheist criticism, and the fifth way", in Theology and Science 12 (2014), pp. 64-77.

[117] Soares, Pedro, et al., "The expansion of mtDNA haplogroup L3 within and out of Africa", in Molecular Biology and Evolution 29 (2012), pp. 915-927.

[118] Spradley, Joseph L., "Ten lunar legacies: Importance of the Moon for life on Earth", in Perspectives on Science and Christian Faith 62 (2010), pp. 267-275. 
[119] Stevenson, David J., "Origin of the moon - The collision hypothesis", in Annual Review of Earth and Planetary Sciences 15 (1987), pp. 271-315.

[120] Stump, J.B., "Did God guide our evolution?", in Perspectives on Science and Christian Faith 72 (2020), 15-24.

[121] Swinburne, Richard, The Existence of God. Second Edition, Oxford University Press, Oxford: 2004.

[122] Sydnor, Jon Paul, "God is not eternal, nor are we: on the blessedness of being in time", in Process Studies 47 (2018), pp. 172-190.

[123] Tabaczek, Mariusz, "An Aristotelian account of evolution and the contemporary philosophy of biology", in The First Virtual International Conference on the Dialogue between Science and Theology: Cosmology, Life \& Anthropology, Ovidius University, Constanta, Romania, 2014, pp. 57-69.

[124] Tabaczek, Mariusz, "Thomistic response to the theory of evolution: Aquinas on natural selection and the perfection of the universe", in Theology and Science 13 (2015), pp. 325-344.

[125] Teixeira, João C., and Cooper, Alan, "Using hominin introgression to trace modern human dispersals", in Proceedings of the National Academy of Sciences of the United States of America 116 (2019), pp. 15327-15332.

[126] Townes, Charles H., "Basic puzzles in science and religion", in Ted Peters and Nathan Hallanger (eds.), God's Action in Nature's World, Essays in Honour of Robert John Russell, Ashgate, Aldershot, UK, 2006, pp. 129-136.

[127] Tucker, Roger, "Fine tuning mission to reach those influenced by Darwinism", in Verbum et Ecclesia 35 (2014), a891, https://doi.org/10.4102/ve.v35i1.891, 06.05.2021.

[128] Ulanowicz, Robert E., "The universal laws of physics", in Robert John Russell and Joshua M. Moritz (eds.), God's Providence and Randomness in Nature: Scientific and Theological Perspectives, Templeton Press, West Conshohocken, PA, 2019, pp. 69-84.

[129] Valley, John W., et al., "Hadean age for a post-magma-ocean zircon confirmed by atom-probe tomography", in Nature Geoscience 7 (2014), pp. 219-223.

[130] Waller, Jason, Cosmological Fine-Tuning Arguments: What (if Anything) Should We Infer from the Fine-Tuning of Our Universe for Life?, Routledge, London, 2019.

[131] Westall, Frances, et al., "Early Archean fossil bacteria and biofilms in hydrothermally-influenced sediments from the Barberton greenstone belt, South Africa", in Precambrian Research 106 (2001), pp. 93-116.

[132] Wilcox, David L., "Genetic insights for human origins in Africa and for later Neanderthal contact", in Perspectives on Science and Christian Faith 66 (2014), pp. 140-153.

[133] Yang, Melinda A., and Fu, Qiaomei, "Insights into modern human prehistory using ancient genomes", in Trends in Genetics 34 (2018), pp. 184-196.

[134] Young, Edward D., et al., "Oxygen isotopic evidence for vigorous mixing during the Moon-forming giant impact", in Science 351 (2016), pp. 493-496. 